\title{
A Deconstructive Reading of Dickinson's Poetic Texts
}

\author{
Aziz Yousif Al-Muttalibi* \\ Al-Mansour University College, Baghdad, Iraq
}

Corresponding Author: Aziz Yousif Al-Muttalibi, E-mail: aziz.yousif@muc.edu.iq

\section{ARTICLE INFO}

Article history

Received: August 17, 2018

Accepted: October 25, 2018

Published: December 28, 2018

Volume: 9 Issue: 6

Advance access: November 2018

Conflicts of interest: None

Funding: None

Key words:

Dickinson,

Derrida,

Deconstruction,

Signs,

Binary Opposition,

Indeterminacy,

Subversion

\begin{abstract}
Deconstruction, as a critical theory, maintains that language is a system of signs and, more precisely, a system of oppositions, differences and contradictions. Accordingly, the theory is operative in the sense that meanings are ultimately, unstable, and that a text, any text, contradicts, dismantles and even destroys itself. Hence, literary texts do not work as they appear to be working. They, in fact, 'subvert' and/or 'betray' themselves. Literary men cannot, therefore, control their works because any work, according to Derrida, the exponent of this theory, tries to defer or suppress its meaning which is ultimately shown as being unstable. Poetry is a unique act and Dickinson's poetry reveals its gaps, inherent oppositions, and subversions. It is in the light of the theory of deconstruction that this paper tries to show that Dickinson's poems 'I'm wife', 'This is my Letter to the World' and 'Hope is the Thing with Feathers' unmask their contradictions and enact the instability and indeterminacy of their meanings. Eventually, the newly established meanings of these pieces can hardly be sure of themselves and/or of being decidable.
\end{abstract}

\section{PREPARATORY REMARKS}

Deconstruction, as a theory, has to create new terms, a thing which explains why Derrida insists on coining new ones. Originally, Derrida borrows the word 'deconstruction' from the work of Martin Heidegger and starts applying it to textual reading. Derrida (1997: 158-159) asserts that there is no outside text. By this, he means that context is essential to his concept of difference (1988: 136). When working out oppositions, Derrida argues against having eventually a nihilistic stand.

Deconstruction does not envisage text, any text, to be distinct separate whole but as having irreconcilable and contradictory aporia of text, hence a deconstructive reading is called aporetic (Curie 80). Miller seems to take things further by refining the reality of the text:

The critical text and the literary text are each parasite and host for the other, each feeding on the other and feeding it, destroying and being destroyed by it. (249)

Casche', on the other hand, argues that deconstruction refines a thoughtful "procedure" and a "marked ... regularity:... deconstruction ... reveals ... a well ordered procedure, a step-by-step type of argumentation based on an acute awareness of ... marked thoroughness and regularity" (3-4). CritChley likes to talk of the ethical aspect of deconstruc- tion. He argues "that Derrida's deconstruction is intrinsically ethical practice" and that "deconstruction involves an openness to the other that makes it ethical in the Levinsan understanding of the term" (352).

In his book, Practicing Theory and Reading Literature: An Introduction, Selden briefly tries to demonstrate a Derridean method at work although he realises that such a thing is "totally un-Derridean in spirit" (89). This is how the Derridean deconstructive critical practice works:

The deconstructor begins by disclosing the hierarchically ordered, metaphysical substratum of a specific piece of discourse. The pairs of terms (soul/body, being/non-being, good/bad, content/form, truth/lies, essential/inessential, speech/writing, masculine/feminine, and so on) are assumed to form a hierarchy of value or truth which allows the writer to exclude from the field of discourse those connotations or meanings which do not accord with the privileged terms. 'Body' is excluded as transitory and inessential; 'form' is superficial and variable; 'feminine' is a defective or weaker form of 'masculine'. The deconstructor proceeds by reversing the hierarchy, not perversely but by discerning a chink in the discourse which allows this reversal. Finally, the newly- asserted 
hierarchy is itself displaced and is not allowed to install a new 'truth' or structural fixity. The rule of indeterminacy prevails. While structuralists had treated binary oppositions ... as stable terms in a formal structure, Derrida sees them as orgnised in unstable disequilibrium. (Selden 89)

\section{POETRY AS A UNIQUE ACT}

The verbal density of poetry makes it a unique act. In his The Well-Wrought Urn, Brooks unleashes his disengaging enunciations concerning poetic discourse: "the language of poetry is the language of paradox" (3). Graves, on the other hand, talks of the need to pay specific attention to poetry:

One doesn't 'listen' when reading standard prose, it is only in poetry that one looks out for metre and rhythmic variation on it. (Graves 8)

Genette recognises that the essence of poetry is determined by the "degree of presence and intensity":

... poetic language would seem to reveal its true 'structure', which is not that of a particular 'form' defined by its specific attribute but rather that of a state, a degree of presence and intensity to which, as it were, any sequence can be brought, if only there is created around it that margin of silence which isolates it in the middle of ordinary speech (but not as deviation). (150)

Apropos, Culler speaks of poetic spirit as having anticipatory 'energy' and of poetic discourse as lying beyond ordinary "communication":

The conventions which enable us to abandon an actual situation of discourse for an invocational- prophetic mode put this latter framework back into the poem as an instance of the energy of anticipation that characterizes the poetical spirit: a spirit which can envision what it calls for. Our ability to perceive that spirit is partly due to the conventions which remove the poem from an ordinary circuit of communication. (166)

Sollers hints at the reader's creativity. His statement on the force of meaning could be extended to encompass the territory of poetry: "in reading we must become aware of what we write unconsciously in our reading" (220). In the following piece, Barthes is not speaking of poetry but about "the force of meaning" in his $S / Z$ which seems to be wholly overwhelming, hence its affinity with poetry:

The force of meaning depends on its degree of systematization: the most powerful meaning is that whose system takes in the greater number of elements, to the point where it seems to encompass everything notable in the semantic universe. (160)

\section{DICKINSON'S POETRY}

Dickinson stands quite eminent in American poetry. However, her thematic concerns are small and intimate-household affairs, daily activities, reflections on intense inner matters. Her poems are usually short. Thus, we have "Faith is a Fine Invention", "The Bustle in a House", "There Came a Wind like a Bugle", "There is a Certain slant of light", "Apparently with No Surprise", etc. Dickinson has been described as "remote" and "unique". However, "while she lived, only seven of her nearly eighteen hundred poems were published, all anonymously and some against her wishes ... Today it is obvious that Emily Dickinson is a poet of major stature and that the poems discovered after her death tied neatly together in little blue packets, are a legacy beyond price" (Safier et al. 320).

In a letter to one of her friends, she, thus, speaks of poetry: "If I read a book and it makes my whole body so cold no fire can ever warm me, I know that is poetry. "If I feel physically as if the top of my head was taken off, I know that is poetry. These are the only ways I know it. Is there any other way?" (Safier et al. 321)

\section{THREE POEMS ANALYSED}

(i) I'm "wife" I've finished that

That other state

I'm Czar I'M "Woman" now-

It's safer so-

How odd the Girl's life looks

Behind this soft Eclipse-

I think that Earth feels so

To folks in Heaven now-

This being comfort then

That other kind was pain-

But why compare?

I'm "Wife"! Stop there!

(Diyani 149-150)

(ii) "This is my letter to the world"

This is my letter to the world

That never wrote to me-

The simple News that Nature told-

With tender Majesty

Her Message is committed

To Hands I cannot see-

For love of Her Sweet countrymen-

Judge tenderly of Me

(Safier et al. 321)

(iii) "Hope Is the Thing with Feathers"

'Hope' is the thing with feathers-

That perches in the soul-

And sings the tune without the words-

And never stops at all

And Sweetest in the Gale is heard-

And sore must be the storm-

That could abash the little Bird

That kept so many warm-

I've heard in the chilliest land-

And on the strangest Sea-

Yet, never, in extremity

It asked a crumb of Me.

(Safier et al. 324)

\section{(i) 'I'm 'wife' — I've finished that"}

A deconstruction reading of "I'm "wife" would look at the inherent binary oppositions operating in the poem. These oppositions transpire as the Girls life/czar, woman/man, heaven/earth, pain/comfort. The first term in this metaphysical hierarchy turns out to be the privileged one, thus cancelling out the second term. However, the privileged status of these terms is undermined through the subversively deflected comparison: 
"But why compare?/I’m 'Wife'! Stop there!” (Lines 11-12)

The instability of the text is quite clear at this point. The poem reveals signs of hesitations in the shape of successive dashes (--), a thing which semantically articulates the undecidability and the indeterminacy of the terms arrived at. Now, the privileged term "the Girl's life" dismantles itself and nothing remains of it except its oddity: "How odd the Girl's life looks/Behind this soft Eclipse ..." (Lines 5-6).

However, the poetess's concept of the term "wife" is sensed in her invocation of 'comfort' at the expense of pain, thus highlighting the term "wife", as temporarily something final and unquestionable. The ambiguity and ambivalence of that("I'm 'wife'.I've finished that" (Line 1) and of there ("I'm 'Wife'! Stop there!" (Line 12) leave meanings suspended, unsure of themselves. Thus, the opening and closing lines of the poetic piece subvert a reality that can never fix itself and that is ever unstable. The absolute power symbolized by czar, a male, is cancelled out by "the girl [...]", a female, who is submerged by wife, a term that suppresses 'husband'. The subverted elements are, thus, unraveled and unmasked.

\section{(ii) "This is My Letter to the World"}

The binary oppositions that operate in the poem appear to be presence/absence, remembering/forgetting, sweetness/ roughness, simplicity/complication, hearing/seeing. Unearthing these oppositions, a deconstructive reader would recognize the first term as privileged over the second which is cancelled out. The poetic lines suggest the poetess's message to a world which is quite forgetful. The poetess(or the speaker) exercises an act of remembering and/or reminding "This is my letter to the world that never wrote to me-" (Lines 1-2). What is present is the "mind" of the writer of the message and the unseen, metaphoric hands of the world.

The message of Dickinson's poetry becomes a thing by the mere fact of being received. However, the sender's assertive confidence seems to fizzle out as soon as she exercises the act of writing. The thing becomes nothing towards the end of the poem. What is assumed to be stable, that is, "tender majesty" (line 4) acquires a sense that could be described as indeterminate - the harshness of the judging reader. Hence, we are left with a sense of reality that can never be closed, that is never final and that, in fact, annihilates itself at every point.

\section{(iii) "'Hope' is the Thing with Feathers."}

The binary oppositions that seem to be operative in the poem are soul/body, hope/despair, warmth/cold, end/start, inward/ outward. The second term of the metaphysical hierarchy is cancelled out, being less privileged than the first. Hope is life and despair is death. Hope, is thus, the thing and despair is the nothing. Soul is permanent and body is temporary. End is maturity and start is naivety. Inward refers to something genuine, and outward suggests that which is superficial.

"'Hope', in the poem, turns into a concrete thing, a little bird "that perches in the soul" (Line 2). This could be, in a luring sense, the difficult birth of the elusive and yet spontaneous and disengaging poetic act that is "physically" felt to take off "the top of" one's "head". However, this new born reality is soon dismantled by hardships that assume concrete manifestations_-: "storm" (Line 6)/“chilliest land" (Line 9) and "Strangest Sea" (Line 10). Thus, a subversive reality that embarrasses (abashes the little bird) (Line 7) is discerned.

However, there exists something of which we are being aware, something which we could draw on when we need to do so. That thing which is nothing, is easy to be there, at any time and in any place, demanding almost nothing. It "sings the tune without word" (Line 3) and it " 'never' in extremity/... asked a crumb of Me" (Lines 11-12). As it is, what has been envisioned as a reality could hardly sustain itself, hence its wavering aspect and hazy existence.

\section{CONCLUSION}

This paper has applied the deconstructive theory to three short poems by Emily Dickinson. Interestingly, it has transpired that the textual meanings are elusive, that they are never present and that they are recognizably deferred. The analysis has tried to discern the metaphysical hierarchy operating in each of these poems. A propos, the concept of binary oppositions, in a poststructuralist sense, has been shown to be very useful in marking the interplay of meanings.

The paper has demonstrated that the signifiers (the words) in these poems are in a constant change, a thing which demonstrates the irreconcilable meanings and the ellipses that are indicative of the complexity of that which the poetess, or more precisely, the poetic voice, wants to convey. Accordingly, the signifying realties of the three poems have been shown to assume ever changing imports that can never be final and that can never be closed. In addition to what has been said earlier about successive dashes, these dashes which occur inside and outside Dickinson's poetic lines attest to the extra implied meanings that the perplexed mind of the poetess strives to embrace.

\section{REFERENCES}

Brathes, Roland. S/Z. Seuil, 1970.

Brooks, Cleanth. The Well-Wrought Urn. Harcourt and Brace, 1974

Casche', Rendolphe. "Infrastructure and Systematicity", Deconstruction and Philosophy, edited by John Sallis, University of Chicago Press, 1987.

Critchley, Simon. The Ethies of Deconstruction: Derrida and Levinas, Edinburgh University Press, 2014.

Culler, Jonathan. Structuralist Poeties: Structuralism, Linguistics and The Study of Literature. Cornell University, 1975.

Curie, Mark. The Invention of Deconstruction. Pulgrave Macmillan, 2013.

Derrida, Jacques. Afterword. Northwestern University Press, 1988.

Of Grammatology. John Hopkins University Press, 1997. 
Diyani, Robert. Poetry: An Introduction. McGraw Hill Higher Education, 2000.

Genette, Ge'rard. Figures II. Seuil, 1969.

Graves, Robert. The Common Asphodel, 1949.

Miller, J. Hillis. "The Critic as Host", Deconstruction and Criticism, The Continuum Publishing Company, 1993.
Selden, Raman. Practising Theory and Reading Literature: An Introduction. Harvester Wheatsheaf, 1989.

Safier, Fannie. Ed., Adventure in American Literature. Holt Rinehart and Winston, 1996.

Sollers, Philippe. Logiques. Seuil, 1968. 